\title{
Exploring the Solvent-Anti-solvent Method of Nanosuspension for Enhanced Oral Bioavailability of Lovastatin
}

\author{
Lovastatinin Gelişmiş Oral Biyoyararlanımı İçin Solvent-Anti-solvent \\ Yöntemi ile Hazırlanan Nanosüspansiyon Formülasyonunun Araştırılması
}

\author{
(D) Archana S. PATIL*, (ID Riya HEGDE, (D) Anand P. GADAD, (D) Panchaxari M. DANDAGI, (D) Rajashree MASAREDDY, (D) Uday BOLMAL \\ Department of Pharmaceutics, KLE College of Pharmacy Belagavi, KLE Academy of Higher Education and Research Belagavi, Karnataka, India
}

\begin{abstract}
Objectives: Lovastatin is an antilipidemic drug that belongs to the class of statins that has poor oral bioavailability due to its low solubility and variable dissolution rate. The main aim of this study was to enhance the solubility and dissolution rate of the drug and understand its oral bioavailability.

Materials and Methods: Lovastatin nanosuspension was formulated using a solventanti-solvent method using a probe sonication technique. A nanosuspension was prepared, using hydroxypropyl methylcellulose (HPMC) K15M and pluronic F68 as stabilizers. The formulated nanosuspensions were characterized for particle size, polydispersity index (PDI) zeta potential, surface morphology, and in vitro release rate. Further, an in vivo bioavailability study and stability studies were also performed.

Results: Optimized formulation showed a particle size of $127 \pm 0.01 \mathrm{~nm}$, a PDI of $0.492 \pm 0.001$, and a zeta potential of $-37.9 \mathrm{mV}$, which indicates good stability. Morphological study showed that the particles were in the nano range. The drug content was found to be in the range of $73-87 \%$. In vitro release revealed much faster release of the drug in one hour compared to the pure drug and its marketed formulation. In vivo bioavailability study was carried out in Wistar rats, which showed improvement in bioavailability by approximately 2.5 folds compared with the marketed formulation. Stability studies indicated that the optimized formulation $\mathrm{F} 2$ was more stable at $4^{\circ} \mathrm{C} \pm 2^{\circ} \mathrm{C}$.

Conclusion: The prepared lovastatin nanosuspension showed improvement in solubility, dissolution rate, and oral bioavailability compared to the pure drug and its marketed formulation. Hence, lovastatin nanosuspension may be a potentially valuable tool for improving the oral bioavailability of lovastatin.
\end{abstract}

Key words: Lovastatin, oral bioavailability, solubility, nanosuspension

öz

Amaç: Lovastatin, düşük çözünürlüğü ve değişken çözünme hızı nedeniyle oral biyoyararlanımı zayıf olan statinler sınıfına ait antilipidemik bir ilaçtır. Bu çalışmanın temel amacı, ilacın çözünürlüğünü ve çözünme hızını artırmak ve oral biyoyararlanımını belirlemektir.

Gereçler ve Yöntemler: Lovastatin içeren nanosüspansiyon, bir prob sonikasyon tekniği kullanılarak solvent-anti-solvent yöntemi kullanılarak formüle edildi. Stabilizatör olarak hidroksipropil metilselüloz (HPMC) K15M ve pluronic F68 kullanılarak bir nanosüspansiyon hazırlandı. Formüle edilen nanosüspansiyonlar, partikül boyutu, polidispersite indeksi (PDI), zeta potansiyeli, yüzey morfolojisi ve in vitro salım profilleri belirlenerek karakterize edildi. Ayrıca, in vivo biyoyararlanım çalışması ve stabilite çalışmaları da gerçekleștirilmiştir.

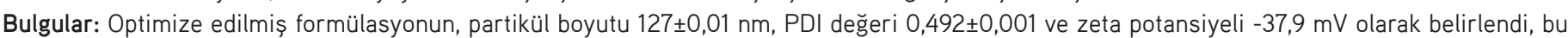
da formülasyonun iyi bir stabiliteye sahip olduğunu gösterdi. Morfolojik çalışma, partiküllerin nano aralıkta olduğunu gösterdi. İlaç içeriği \%7387 aralığında bulundu. In vitro salım, saf ilaca ve ticari formülasyona kıyasla ilacın bir saat içinde çok daha hızlı salım profili gösterdiğini ortaya çıkardı. In vivo biyoyararlanım çalışması Wistar sıçanlarında gerçekleştirildi ve nanosüspansiyon formülasyonunda ticari formülasyona kıyasla biyoyararlanımda yaklaşık 2,5 kat iyileșme olduğunu gösterdi. Stabilite çalıșmaları, optimize edilmiş $\mathrm{F} 2$ formülasyonunun $4^{\circ} \mathrm{C} \pm 2^{\circ} \mathrm{C}$ 'de daha stabil olduğunu gösterdi. 
Sonuç: Hazırlanan lovastatin nanosüspansiyonu, saf ilaca ve ticari formülasyonuna kıyasla çözünürlük, çözünme hızı ve oral biyoyararlanım açısından gelișme göstermiștir. Bu nedenle, lovastatin nanosüspansiyonunun, lovastatinin oral biyoyararlanımını geliștirmek için potansiyele sahip olduğu sonucuna ulaşıldı.

Anahtar kelimeler: Lovastatin, oral biyoyararlanım, çözünürlük, nanosüspansiyon

\section{INTRODUCTION}

Oral route is the highly preferred route for administration of drugs as it provides high patient compliance.' A large number of drugs that are available in the market exhibit low oral bioavailability because of their low aqueous solubility and intrinsic dissolution rate. According to the Biopharmaceutical Classification System, drugs with poor aqueous solubility are classified either as class II or class IV drugs. ${ }^{2}$ Poor aqueous solubility of the drugs results in low oral bioavailability, varying absorption rate, and inter/intrasubject proportionality. ${ }^{3}$ Oral bioavailability of various drugs is also affected by another factor (i.e., poor gastrointestinal permeability). According to the literature, various techniques like solubilization, salt formation, micronization, change in physical form, use of prodrug and drug derivatives, addition of surfactants, and $\mathrm{pH}$ alteration have been utilized for improving the dissolution and bioavailability of the drugs having poor aqueous solubility. ${ }^{4}$

Nanotechnology has reshaped the field of drug delivery and research. Pharmaceutical nanoparticles are solid submicron sized ( $<100 \mathrm{~nm}$ in diameter) drug carriers that may or may not be biodegradable. ${ }^{5}$ Types of nanoparticles that are applied in drug delivery include nanosuspensions, polymeric nanoparticles, and lipid nanoparticles. Nanosuspension is the colloidal dispersion of solid drug particles in a liquid phase having a particle size of $\langle 1 \mu \mathrm{m}$ with an average particle size of 200$600 \mathrm{~nm}^{.}{ }^{6}$ It consists of pure drug and stabilizers (surfactants or polymers). Their small particle size facilitates effective transportation of drug molecules to cells with an optimum therapeutic effect and reduced adverse effects. ${ }^{7}$ The potential benefits of nanosuspension technology for poorly soluble drug delivery are increased drug dissolution rate, increased rate, and extent of absorption, and hence the bioavailability of drugs. The selection of a suitable stabilizer or surfactant as well as the manufacturing method may offer nanosuspension with highest stability for long-term storage. Nanosuspension may be formulated by a bottom-up or top-down approach.

Cardiovascular disease remains the leading cause of morbidity and mortality worldwide, and hyperlipidemia is a major factor contributing to its development. ${ }^{8}$ Lovastatin is a cholesterollowering agent that has been isolated from a strain of Aspergillus ferreus. It is very effective and well tolerated by patients with moderate hypercholesterolemia. Lovastatin also manifests pharmacological activities of bone formation and chemoprevention. Due to its rapid metabolism in the gut and liver, lovastatin exhibits poor oral bioavailability of $\langle 5 \%$ and a shorter half-life of 2-5 h. ${ }^{9}$ According to the literature, various attempts have been made to improve the aqueous solubility and bioavailability of lovastatin by preparing self-emulsifying drug delivery systems, nanostructured lipid carriers (NLC), and extended-release formulation by one-step melt granulation method. For instance, Sunil et al..$^{10}$, Jun and Daxin ${ }^{11}$ and Gande et al..$^{12}$ prepared stabilized self-emulsifying drug delivery systems in the form of hydrogel, NLC, and solid lipid nanoparticles (SLN) of lovastatin, respectively, with an objective to enhance the solubility and bioavailability of lovastatin, but there are no comparative data of their formulation with the already existing marketed product to justify the enhancement in bioavailability of the drug.

Hence, attempts were made to improve solubility and oral bioavailability of lovastatin by formulating lovastatin nanosuspension via the solvent-anti-solvent method using probe sonication technique in this study. Further, nanosuspensions were evaluated for particle size, polydispersity index (PDI), zeta potential, drug content, an in vitro release study, in vivo bioavailability study, and stability study.

\section{MATERIALS AND METHODS}

\section{Materials}

Lovastatin was procured as a gift sample from Lupin Pharmaceuticals, Goa. Hydroxypropyl methylcellulose (HPMC) K15M was purchased from Yarrow Chem Products, Mumbai. Pluronic F68 was purchased from Ozone Pharmaceuticals, Mumbai. Acetone, Chloroform, Methanol, and Ethanol were purchased from Molychem, Mumbai. Dialysis membrane having a cutoff molecular weight between 12,000 and 14,000 Dalton was purchased from Hi Media.

\section{Methods}

\section{Optimization of process parameters}

\section{Selection of a suitable solvent-anti-solvent ratio}

Before proceeding toward formulation of the lovastatin nanosuspension, a solvent and anti-solvent were selected based on the solubility studies of drugs in different solvents. In the solvent-anti-solvent method, the selected solvent should be a water-miscible solvent and capable enough to dissolve the drug to a greater extent so that a clear solution is obtained. Conversely, the solvent in which the drug was least soluble or was completely insoluble was selected as an anti-solvent. As the drug exhibits maximum solubility in methanol, it was selected as a solvent, and water was selected as an antisolvent since the drug was least soluble in water. Different ratios like 1:1, 1:2, 1:3, 1:4, and 1:5 were tried for formulating a nanosuspension. The ratio of solvent:anti-solvent that resulted in a production of nanosuspension with the best reproducible particle size, and PDI was selected as an optimized ratio. 


\section{Optimization of sonication time}

Optimization of sonication time was done by sonicating the formulation for 2, 5, 10, 15, and 20 mins. Based on the best and reproducible results of particle size and PDI, an optimized sonication time was selected.

\section{Selection of polymer and surfactant}

A suitable polymer was selected by screening various polymers like HPMC K15M, HPMC K100M, and PVPK30. Based on the best and reproducible results of particle size, PDI, and the ability to inhibit crystal growth, a suitable polymer was selected. Various surfactants like pluronic F68, pluronic F127, and polyethylene glycol 6000 were tested to determine the surfactant effective in reducing the particle size of the drug.

\section{Effect of flow rate}

Particle size of the obtained nanosuspension was measured at varied flow rates of drug solution into polymer solution at 2-8 $\mathrm{mL} / \mathrm{min}$ to select the optimum flow rate during the formulation of nanosuspension. All the process optimization parameters are depicted in Table 1.

Formulation of nanosuspension by solvent-anti solvent technique

Six formulations of (F1-F6) lovastatin nanosuspensions were prepared by the solvent-anti-solvent method using a probe sonication technique. Briefly, a specified amount of drug was completely dissolved in the water-miscible solvent (methanol). In another beaker, polymer/surfactant was added to the water (anti-solvent) and further sonicated till a clear polymeric solution was formed. The prepared drug solution was then added to the polymeric solution at a rate of $2 \mathrm{~mL} / \mathrm{min}$ and maintained in an ice bath to prevent particle collision till precipitation occurred. ${ }^{13-16}$ The quantities of ingredients used in the formulation are mentioned in Table 2, and the solvent-antisolvent technique is depicted in Figure 1.

\section{Evaluation of lovastatin-loaded nanosuspensions}

\section{Particle size analysis}

The particle size of the prepared nanosuspension was determined using a dynamic light scattering (DLS) particle size analyzer. For analysis, the nanosuspension was diluted with Millipore water at a ratio of 1:5 and further sonicated for $2 \mathrm{~min}$. Samples were analyzed in triplicate. ${ }^{17}$

\section{Polydispersity index}

PDI is also measured using a DLS particle size analyzer. The obtained PDI values give an idea about the particle size distribution of nanoparticles. Their values range from 0.000 to 1.000, which demonstrate that the lower the value, the narrower the size distribution of nanoparticles and vice versa. ${ }^{18}$

Table 1. Optimization of process parameters and their evaluation

Optimization of the solvent:anti-solvent ratio and sonication time

\begin{tabular}{lllll}
\hline Solvent (methanol):anti-solvent (water) ratio & $1: 1$ & $1: 2$ & $1: 3$ & $1: 4$ \\
\hline Sonication time (min) & 05 & 10 & 15 & 20 \\
\hline Particle size (nm) & 1595 & 623 & 407 & 379 \\
\hline PDI & 1.6 & 1.5 & 0.04 & 0.4 \\
\hline
\end{tabular}

Effect of polymer on particle size and PDI

\begin{tabular}{lll}
\hline Polymer & Particle size $(\mathrm{nm})$ & PDI \\
\hline HPMC K15M & 483 & 0.5 \\
\hline HPMC K100M & 1054 & 0.5 \\
\hline PVP K30 & 1064 & 0.5 \\
\hline
\end{tabular}

Effect of a surfactant on particle size and PDI

\begin{tabular}{lll}
\hline Surfactant & Particle size $(\mathrm{nm})$ & PDI \\
\hline PEG 6000 & 1205 & 1.9 \\
\hline Pluronic F127 & 926 & 0.4 \\
\hline Pluronic F68 & 442 & 0.6 \\
\hline
\end{tabular}

Effect of flow rate on particle size and PDI

\begin{tabular}{lll}
\hline Flow rate & Particle size $(\mathrm{nm})$ & PDI \\
\hline $2 \mathrm{~mL} / \mathrm{min}$ & 487 & 0.4 \\
\hline $4 \mathrm{~mL} / \mathrm{min}$ & 604 & 0.5 \\
\hline $6 \mathrm{~mL} / \mathrm{min}$ & 798 & 0.5 \\
\hline $8 \mathrm{~mL} / \mathrm{min}$ & 1023 & 0.6 \\
\hline
\end{tabular}

PDI: Polydispersity index, HPMC: Hydroxypropyl methylcellulose, PVP: Polyvinylpyrrolidone, PEG: Polyethylene glycol 
Table 2. Formulation design of lovastatin nanosuspension using the solvent-anti-solvent method

\begin{tabular}{|c|c|c|c|c|c|}
\hline Formulation number & Lovastatin (mg) & HPMC K15M (mg/mL) & Pluronic F68 (mg/mL) & Methanol (mL) & Water $(\mathrm{mL})$ \\
\hline F1 & 10 & 1.0 & - & 10 & 50 \\
\hline F2 & 10 & 1.5 & - & 10 & 50 \\
\hline F3 & 10 & - & 1.0 & 10 & 50 \\
\hline F4 & 10 & - & 1.5 & 10 & 50 \\
\hline F5 & 10 & 1.0 & 1.5 & 10 & 50 \\
\hline F6 & 10 & 1.5 & 1.0 & 10 & 50 \\
\hline
\end{tabular}

HPMC: Hydroxypropyl methylcellulose

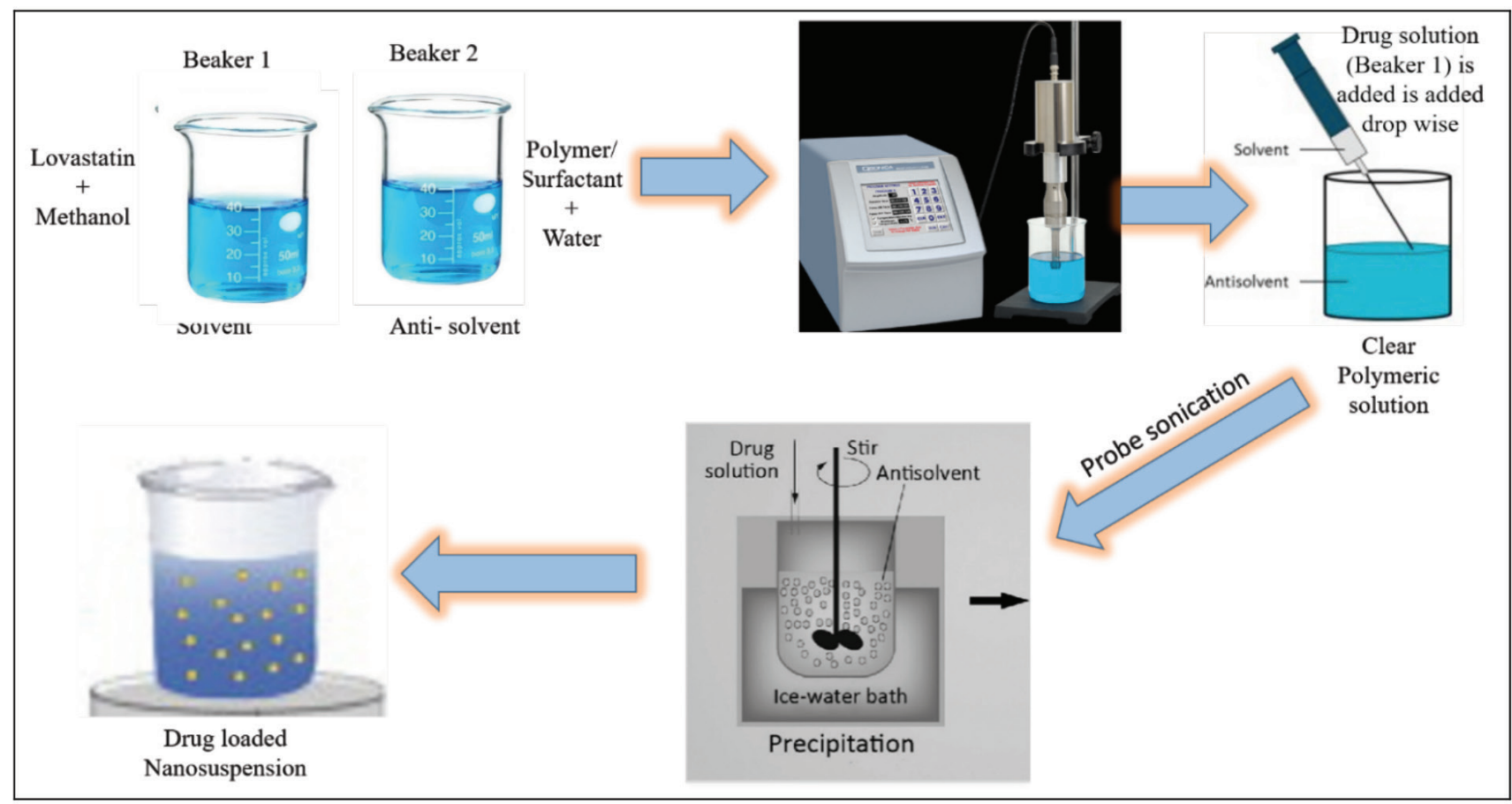

Figure 1. Formulation of nanosuspension by the solvent-anti-solvent technique

\section{Drug content}

Lovastatin nanosuspension was equivalent to $1 \mathrm{mg}$ and was added to $10 \mathrm{~mL}$ of methanol; it was further diluted with a phosphate buffer up to $100 \mathrm{~mL}$ and stirred continuously for $2 \mathrm{~h}$. It was subjected to ultracentrifugation at 15,000 rpm for $20 \mathrm{~min}$. The supernatant was collected, suitably diluted, and analyzed spectrophotometrically at $238 \mathrm{~nm} .^{19}$

\section{Zeta potential}

A physical property exhibited by particles in suspension is zeta potential. It is used for the optimization of emulsions and suspensions as its knowledge reduces the number of trial formulations. It is also an important parameter to predict longterm stability. ${ }^{20}$

\section{Transmission electron microscopy (TEM)}

The external morphology of lovastatin nanosuspension was studied using TEM, and it was performed at SAIF, Cochin.
Samples for TEM were prepared by initially diluting with Millipore water. Then, a drop of nanosuspension was kept on a copper grid (carbon coated) and stained with phosphotungstic acid. The grid was air dried and observed at different magnifications under TEM. ${ }^{21}$

\section{In vitro drug release study}

The in vitro drug release of lovastatin was performed using the dialysis bag diffusion technique. An accurately weighed quantity of nanosuspension (equivalent to $10 \mathrm{mg}$ of the drug) was placed in a dialysis bag, and the bag was sealed. Then, the bag was suspended initially for $1 \mathrm{~h}$ in a basket containing $900 \mathrm{~mL}$ of $\mathrm{pH} 6.8$ phosphate buffer. Aliquots of $5 \mathrm{~mL}$ of the sample were withdrawn at pre-determined intervals from the compartment, and the same amount was replaced by the fresh buffer. The sample was analyzed spectrophotometrically after suitable dilution by determining the absorbance at $238 \mathrm{~nm} .^{22}$ 
In vivo bioavailability study

Healthy Wistar rats weighing 180-200 g were housed in polypropylene cages and maintained at room temperature for 12 $\mathrm{h}$ dark/light cycles. They were fed with standard pelleted diet and water. The animals were acclimatized for one week under laboratory conditions before experiments were done on the animals. Ethical clearance was obtained from the Institutional Animal Ethics Committee (resolution no: KLECOP/CPCSEA/ Re.no.221/PO/RE/S/2000/CPCSEA Res.27-24/12/2018) prior to the beginning of the research. The in vivo study was aimed to mainly estimate the amount of drug in the blood withdrawn from rats at various time intervals. ${ }^{23}$

Twelve healthy male Wistar rats weighing 180-200 gms were selected and divided into two groups, each containing six rats. Group 1 received the marketed product of lovastatin, and group 2 received lovastatin nanosuspension equivalent to $0.108 \mathrm{mg}$ in normal saline through the oral route. After $0.5,2,4,6,8,10$, and $24 \mathrm{~h}, 0.5-1 \mathrm{~mL}$ blood was collected from the tail vein into an Eppendorf tube containing 10- $\mu$ L EDTA and centrifuged at 5000 rpm for $20 \mathrm{~min}$. Supernatant plasma was collected, filtered through a $0.45 \mu \mathrm{m}$ membrane into clean vials and analyzed spectrophotometrically to determine the concentration.

\section{Short term stability studies}

The optimized formulation was subjected to stability studies as per International Council on Harmonisation (ICH) guidelines. The formulation was exposed to varying conditions of temperature and relative humidity, i.e., $25^{\circ} \mathrm{C} / 65 \% \mathrm{RH}$ and $4^{\circ} \mathrm{C} / 65 \% \mathrm{RH}$, for a period of three months in a humidity control oven. The samples were collected and evaluated for particle size and percent cumulative drug release at intervals of $0,1,2$, and 3 months, respectively.

\section{RESULTS AND DISCUSSION}

\section{Optimization of process parameters}

For the drug lovastatin, maximum solubility was observed in methanol, and least solubility was observed in water. Hence, methanol was selected as a solvent and water as an antisolvent. Based on the effect of the solvent: anti-solvent volume ratio on particle size, a 1:4 ratio was considered optimum as the particle size was obtained in the nano range. Based on the best and reproducible results, the optimized sonication time was found to be 20 mins, which produced particles in the nano range.

Polymer screening was performed using various polymers like HPMC K15M, HPMC K100M, and PVPK30. Particle size was measured immediately after precipitation. HPMC K15M was found to be more effective in inhibiting crystal growth as compared to particles prepared without the use of a polymer. Hence, HPMC K15M was selected as the stabilizer for the experiment. Pluronic F68 surfactant was found to have more potential as the obtained particle size of nanosuspension was observed in the nano range.

It was observed that an increase in flow rate $(2-8 \mathrm{~mL} / \mathrm{min})$ increased the particle size from $487 \mathrm{~nm}$ to $1023 \mathrm{~nm}$ because of large crystal formations. Hence, a flow rate of $2 \mathrm{~mL} / \mathrm{min}$ was found to be optimum to get the particle size in the nano range. The process optimization parameters and their evaluation results are depicted in Table 1.

\section{Formulation of nanosuspension by the solvent-anti-solvent technique}

Lovastatin nanosuspension was successfully prepared by the solvent-anti-solvent method using a probe sonication technique. A total of six formulations were prepared using HPMC K15M and pluronic F68 as stabilizers. In the technique, the addition of the drug solution to the anti-solvent leads to higher supersaturation. This produces many nuclei because of a high nucleation rate, which in turn reduces the mass of the solute for subsequent growth. Submicron particles are thus produced, provided that the nucleating crystals' growth is arrested by the stabilizer via stearic or electrostatic mechanism. Because lovastatin is a hydrophobic drug, the most generally used anti-solvent is water. With respect to the solvent, it has more potential if it solubilizes a higher amount of drug and possesses a greater diffusion rate to the anti-solvent, whereas the stabilizer should possess good affinity toward the drug particles and result in a fast diffusion rate as well as sufficient adsorption onto the surface of the drug particles in the solvent-water mixture. Hence, a pair of solvent-stabilizer is crucial to achieve the submicron particles. ${ }^{24}$

\section{Evaluation of lovastatin-loaded nanosuspension}

\section{Particle size analysis}

Particle size of the prepared formulation was determined to confirm the production of the particles in the nano range. All formulations were found to be in the range of 127-401 nm (Table 3). It was observed that the particle size was decreased from $284 \mathrm{~nm}$ to $127 \mathrm{~nm}$, as the HPMC concentration increased from $1.0 \mathrm{mg} / \mathrm{mL}$ to $1.5 \mathrm{mg} / \mathrm{mL}$. This is attributed to the good affinity of the hydrophobic portion of HPMC for drug particles, which leads to an effective stearic barrier against growth. Similarly, when the concentration of pluronic F68 increased from $1.0 \mathrm{mg} /$ $\mathrm{mL}$ to $1.5 \mathrm{mg} / \mathrm{mL}$, the particle size decreased from $401 \mathrm{~nm}$ to $239 \mathrm{~nm}$. This result may be due to the high affinity of lovastatin particles toward this stabilizer, which provided an effective stearic barrier against crystal growth. Additionally, particle size of the formulations containing the combination of both HPMC $\mathrm{K} 15 \mathrm{M}$ and pluronic F68 (F5 and F6) were in the nano range.

\section{Polydispersity index}

PDI determines particle size distribution, which ranges from 0 to 1 . The sample is said to be monodisperse when the PDI value is close to zero. When the PDI value is $\langle 0.2$, it is regarded as a narrow size distribution. PDI of all the formulations are shown in Table 3. However, when the PDI value is $>0.2$, it is considered as polydisperse distribution. Among the prepared nanosuspension formulation, F1 and F3 showed monodisperse size distribution with PDI values of 0.28 and 0.048 , respectively. F2, F4, F5, and F6 exhibited polydisperse-sizes distributions with PDI values of $0.492,0.81,0.61$, and 0.30 , respectively. 


\section{Zeta potential}

The zeta potential was analyzed to determine the stability of the optimized formulation. The zeta potential of the optimized formulation was found to be $-37.9 \mathrm{mV}$, which indicates good stability.

\section{Transmission electron spectroscopy}

TEM images of the optimized formulation F2 revealed that the particles were spherical in shape, evenly distributed, and were in the range of $64.62-157.82 \mathrm{~nm}$, which is close to the value obtained from the particle size analyzer (Nanotrac). TEM images are shown in Figure 2.

\section{Drug content}

Drug content was calculated for the formulations F1-F6, and it was found to be in the range of $73-86.29 \%$. Drug content was found to be maximum for the formulation F2 and least for the formulation F3.

\section{In vitro drug release study}

An in vitro drug release study performed in phosphate buffer $(\mathrm{pH}$ 6.8) for $1 \mathrm{~h}$ to check the release of drug is depicted in Figure 3. The results indicated that the formulation F2 with the least particle size showed a maximum release rate. Based on the drug content, particle size, and drug release profile, the formulation F2 was selected as an optimized formulation. The release profile of the optimized formulation was then compared to the release profile of the pure drug and its marketed formulation, as shown in Figure 4. The percent cumulative drug release obtained at the end of $1 \mathrm{~h}$ for optimized, marketed,

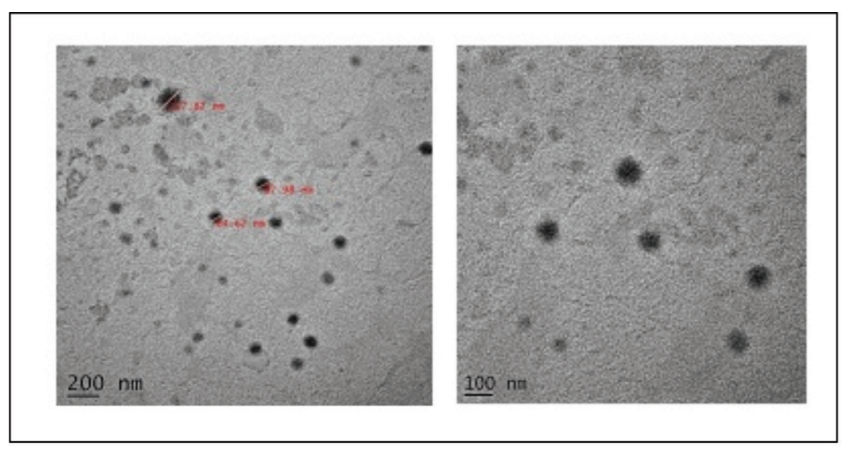

Figure 2. Transmission electron microscopy images of the optimized formulation F2 and pure drug formulations were $92.83 \%, 60.47 \%$, and $39.73 \%$, respectively. This is because smaller the particle size, larger the surface area. Hence, the drug that is at or near the surface is easily released.

\section{In vivo bioavailability study}

The study was performed in Wistar rats to compare the plasma concentration of the optimized formulation F2 with that of the marketed product given orally in a normal saline. The average concentration was obtained at regular intervals for both the formulations. A comparative graph of plasma concentration vs. time of the optimized formulation F2 and the marketed product is shown in Figure 5. This graph revealed that the formulation F2 showed a greater bioavailability than that of the marketed product. Area under the concentration (AUC) of $29.34 \mu \mathrm{g} \mathrm{h} / \mathrm{mL}$, $\mathrm{C}_{\max }$ of $4.9 \mathrm{\mu g} / \mathrm{mL}$, and $\mathrm{T}_{\max }$ of $4 \mathrm{~h}$ was observed for the marketed product when given orally. However, the optimized formulation showed AUC of $63.05 \mu \mathrm{g} \mathrm{h} / \mathrm{mL}, C_{\max }$ of $6.5 \mu \mathrm{g} / \mathrm{mL}$, and $T_{\max }$ of $1 \mathrm{~h}$, which was calculated by the trapezoidal method (Table 4). Thus, the lovastatin nanosuspension was able to improve the bioavailability by approximately 2.5 folds when compared to the marketed product.

Few more studies have been conducted with respect to the bioavailability enhancement of lovastatin. For instance, Roshan

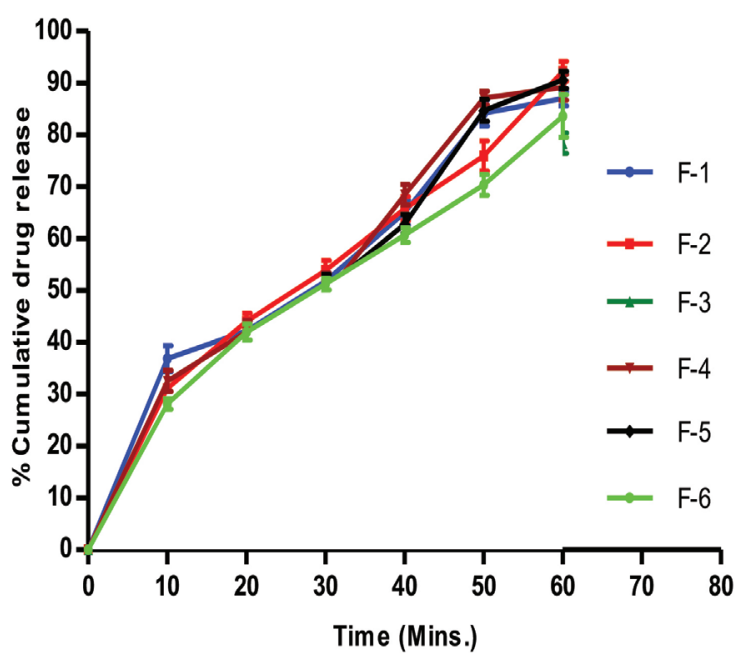

Figure 3. In vitro drug release profile for all the formulations

Table 3. Particle size, polydispersity index, percent drug content, and percent CDR of the nanosuspension formulations F1-F6

\begin{tabular}{lllll} 
Formulation code & Particle size $(\mathrm{nm})$ & PDI $(\mathrm{Mv})$ & Drug content $\%$ & CDR \% \\
\hline F1 & $284 \pm 0.04$ & $0.28 \pm 0.022$ & $76.90 \pm 08$ & $87.44 \pm 06$ \\
\hline F2 & $127 \pm 0.01$ & $0.492 \pm 0.001$ & $86.33 \pm 07$ & $92.83 \pm 08$ \\
\hline F3 & $401 \pm 0.06$ & $0.048 \pm 0.004$ & $73.25 \pm 06$ & $78.19 \pm 07$ \\
\hline F4 & $239 \pm 0.002$ & $0.81 \pm 0.003$ & $78.02 \pm 06$ & $89.53 \pm 05$ \\
\hline F5 & $224 \pm 0.02$ & $0.61 \pm 0.005$ & $82.51 \pm 08$ & $90.33 \pm 06$ \\
\hline F6 & $319 \pm 0.03$ & $0.30 \pm 0.02$ & $74.00 \pm 05$ & $80.25 \pm 05$ \\
\hline
\end{tabular}

Data are expressed as the mean \pm SD $(n=3)$. CDR: Constant default rate, PDI: Polydispersity index, SD: Standard deviation 
Table 4. Pharmacokinetic parameters of marketed formulation and optimized formulation F2

\begin{tabular}{llll} 
Formulation & $\mathrm{C}_{\max }(\mu \mathrm{g} / \mathrm{mL})$ & $\mathrm{T}_{\max }(\mathrm{h})$ & $\mathrm{AUC}_{0-\mathrm{t}}(\mu \mathrm{g} / \mathrm{mL} / \mathrm{h})$ \\
\hline $\mathrm{F} 2$ & 6.5 & 01 & 63.05 \\
\hline Marketed product & 4.9 & 04 & 29.34 \\
\hline $\mathrm{C}_{\max }:$ Maximum plasma concentration, $\mathrm{T}_{\max }:$ Time of maximum plasma concentration, AUC $\mathrm{C}_{0-\mathrm{t}}:$ Area under the concentration-time curve from dosing (time 0) to time $t$
\end{tabular}

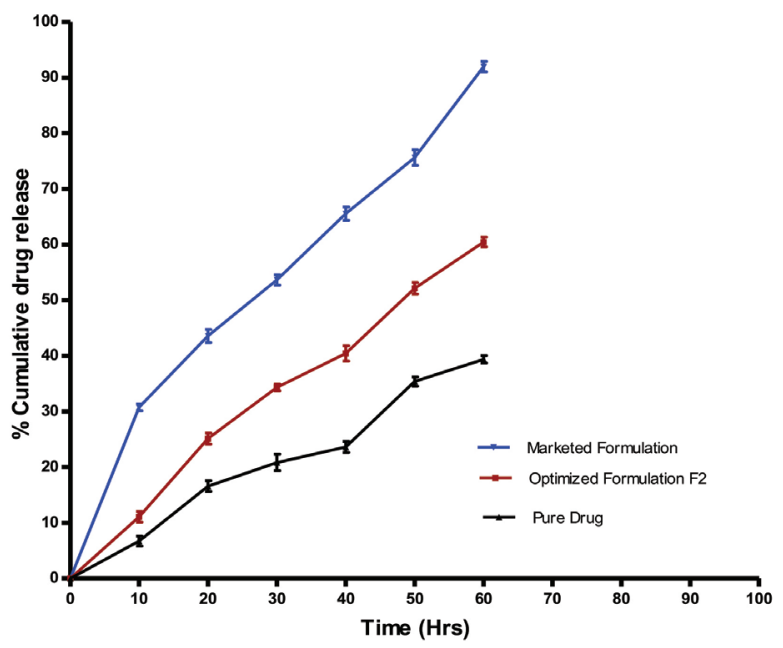

Figure 4. Comparison of in vitro drug release profile of the optimized formulation (F2) with that of a pure drug and marketed formulation

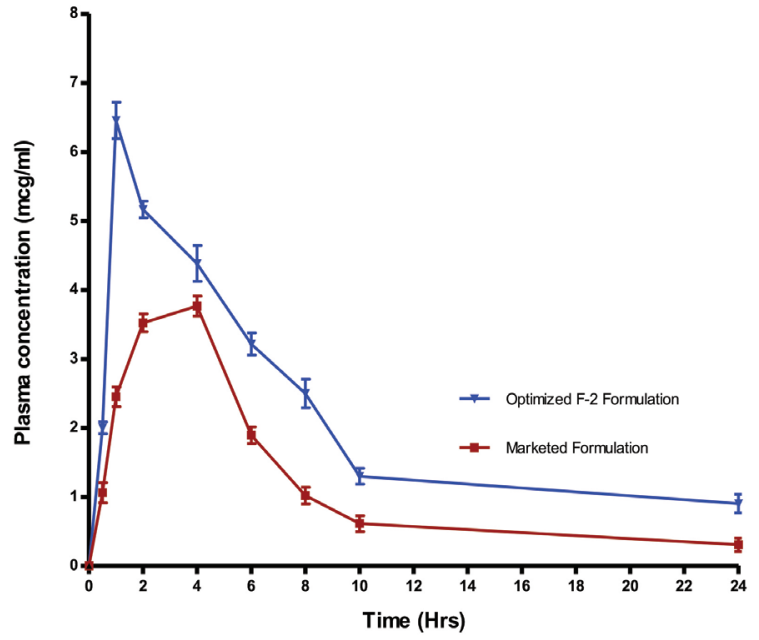

Figure 5. In vivo plasma drug concentration time curve of the optimized formulation (F2) and marketed formulation

et al. ${ }^{25}$ performed comparative in vivo pharmacokinetic studies among solid lipid nanoparticle SLN carrier and NLC and concluded that the lovastatin-encapsulated NLC presented increased bioavailability (10.56\%) compared to SLN (7.5\%). Keerthi and Bhikshapath ${ }^{26}$ developed a self-nanoemulsifying drug delivery system (SNEDDS) of lovastatin to increase its solubility and bioavailability. This study concluded that the optimized formulation of SNEDDS significantly improved the oral bioavailability of lovastatin as compared with the pure drug (no comparison with the marketed product). ${ }^{26}$ Recently, Gaber ${ }^{27}$ prepared and optimized nanoparticles by an ultrasonicationassisted precipitation method. In vivo studies confirmed that there was a 1.45 -fold enhancement in $C_{\max }$ of lovastatin nanoparticles as compared to a marketed tablet. ${ }^{27}$ These studies have also led to enhanced bioavailability of the drug, but not to the extent of a 2.5-fold increment compared with the marketed product. Thus, a developed nanosuspension by the solvent-anti-solvent method may be a potential technique to produce submicron particles of poorly water-soluble drugs, thereby enhancing oral bioavailability.

\section{Short-term stability studies}

Stability studies were conducted for the optimized formulation F2 as per ICH guidelines for a period of 3 months. Physical appearance of $\mathrm{F} 2$ changed slightly when samples were stored at room temperature $25^{\circ} \mathrm{C} \pm 2^{\circ} \mathrm{C} / \mathrm{RH} 65 \% \pm 5 \%$ for 3 months. $A$ sediment of thin layer was observed. However, it disappeared immediately with slight shaking. No change in the physical appearance was observed when nanoparticles were stored in the refrigerator at $4^{\circ} \mathrm{C} \pm 2^{\circ} \mathrm{C} / \mathrm{RH} 65 \% \pm 5 \%$ for 3 months. On comparing the stability study data with the initial data, it was observed that there was not much change in the particle size and the in vitro drug release for the formulation stored at $4^{\circ} \mathrm{C} \pm 2^{\circ} \mathrm{C} / \mathrm{RH} 65 \% \pm 5 \%$ to that stored at room temperature. Thus, the formulation stored at $4^{\circ} \mathrm{C} \pm 2^{\circ} \mathrm{C} / \mathrm{RH} 65 \% \pm 5 \%$ showed better stability as compared to the formulation stored at $25^{\circ} \mathrm{C} \pm 2^{\circ} \mathrm{C} / \mathrm{RH}$ $65 \% \pm 5 \%$.

\section{CONCLUSION}

In the present study, the solvent-anti-solvent method was employed to formulate nanosuspension of lovastatin for enhancing the solubility, dissolution rate, and thereby its oral bioavailability. Lovastatin nanosuspension was formulated using methanol as a solvent, water as an anti-solvent, and HPMC K15M and Pluronic F68 as stabilizers. Fourier transform infrared spectroscopy and differential scanning calorimetry studies showed no interaction between the drug and the excipients that were used in the formulation (results not shown). On the basis of drug content, particle size, and drug release profile, formulation F2 was selected as an optimized formulation. TEM images suggest that the particle size of all the formulations were in the nano range. Zeta potential of optimized formulation F2 was found to be $-37.9 \mathrm{mV}$, which showed a good stability. The dissolution rate depends upon the particle size. The smaller the particle size, the faster will be the dissolution. Formulation F2 showed a maximum dissolution rate of $92.83 \%$ in $1 \mathrm{~h}$ when compared with the pure drug and the marketed formulation, which showed $39.73 \%$ and $60.47 \%$ dissolution in the same time. A pharmacokinetic analysis of in vivo bioavailability data 
indicated a 2.5-fold increase in comparison with the marketed formulation. Stability studies were conducted according to $\mathrm{ICH}$ guidelines for optimized formulation $\mathrm{F} 2$, and it was more stable at $4^{\circ} \mathrm{C} \pm 2^{\circ} \mathrm{C}$. Thus, it may be concluded that the solvent-antisolvent method is a simple and potential technique to produce submicron particles of poorly water-soluble drugs, thereby enhancing oral bioavailability for commercial production.

\section{ACKNOWLEDGMENTS}

The authors would sincerely like to thank Lupin Pharmaceuticals, Goa for providing a gift sample of lovastatin. The authors are also thankful to the principal of KLE College of Pharmacy, Belagavi and Dr. Prabhakar Kore Basic Science Research Centre, Belagavi for providing laboratory facilities. The authors are thankful to Kesar Control System, AICTE-MODROB 20172018 for providing the stability chamber to carry out the stability studies for this research. The authors are also thankful to AICTE-MODROBE for providing the Ultrasonic probe sonicator VC750.

Conflict of interest: No conflict of interest was declared by the authors. The authors are solely responsible for the content and writing of this paper.

\section{REFERENCES}

1. Heran Z, Jin H, Yihua Y, Erxi C. Development of novel mesoporous nanomatrix-supported lipid bilayers for oral sustained delivery of the water-insoluble drug, lovastatin. Colloids Surf B. 2015;128:77-85.

2. Preshita PD, Abhijit AD, Vandana BP. Overcoming poor oral bioavailability using Nanoparticle formulations opportunities and limitations. Drug Discov Today Technol. 2012;09:87-95.

3. Sandip C, Garima J, Kailash P, Krutika S. Enhanced bioavailability and hypolipidemic activity of Simvastatin formulations by particle size engineering: Physicochemical aspects and in vivo Investigations. Biochem Eng J. 2013;79:221-229.

4. Konwar R, Ahmed AB. Nanoparticle: an overview of preparation, characterization and application. Int Res J Pharm. 2013;4:47-57.

5. Ying X, Wei W, Zongning Y, Ruyue L. Enhanced dissolution and oral bioavailability of Aripiprazole Nanosuspensions prepared by nanoprecipitation/homogenization based on acid-base neutralization. Int J Pharm. 2012;438:287-295.

6. Alptug K, Zeynep ST, Hakan E, Nevin C. Evaluation of improved oral bioavailability of Ritonavir Nanosuspension. Eur J Pharm Sci. 2019;131:153-158.

7. Chia HC, Jyh CY, Yow SU, Chun JL. Improved dissolution rate and oral bioavailability of Lovastatin in red yeast rice products. Int J Pharm. 2013;444:18-24.

8. Roth GA, Mensah GA, Johnson CO, Addolorato G, Ammirati E, Baddour LM, Barengo NC, Beaton AZ, Benjamin EJ, Benziger CP, Bonny A, Brauer M, Brodmann M, Cahill TJ, Carapetis J, Catapano AL, Chugh SS, Cooper LT, Coresh J, Criqui M, DeCleene N, Eagle KA, Emmons-Bell S, Feigin VL, Fernández-Solà J, Fowkes G, Gakidou E, Grundy SM, He FJ, Howard G, Hu F, Inker L, Karthikeyan G, Kassebaum N, Koroshetz W, Lavie C, Lloyd-Jones D, Lu HS, Mirijello A, Temesgen AM, Mokdad A, Moran AE, Muntner P, Narula J, Neal B, Ntsekhe M, Moraes de Oliveira G, Otto C,
Owolabi M, Pratt M, Rajagopalan S, Reitsma M, Ribeiro ALP, Rigotti N, Rodgers A, Sable C, Shakil S, Sliwa-Hahnle K, Stark B, Sundström J, Timpel P, Tleyjeh IM, Valgimigli M, Vos T, Whelton PK, Yacoub M, Zuhlke L, Murray C, Fuster V; GBD-NHLBI-JACC Global Burden of Cardiovascular Diseases Writing Group. Global Burden of Cardiovascular Diseases and Risk Factors, 1990-2019: Update From the GBD 2019 Study. J Am Coll Cardiol. 2020;76:2982-3021.

9. Chih CC, Tung HT, Zih RH, Jia YF. Effects of lipophilic emulsifiers on the oral administration of lovastatin from nanostructured lipid carriers: Physicochemical Characterization and Pharmacokinetics. Eur J Pharm Biopharm. 2010;74:474-482.

10. Sunil KY, Jitendra BN, Jayesh SP, Vinod JM, Ruby S. Enhanced solubility and bioavailability of Lovastatin using stabilized form of self-emulsifying drug delivery system. Colloids Surf A. 2015;481:63-71.

11. Jun Z, Daxin Z. Improvement of oral bioavailability of Lovastatin by using nanostructured lipid carriers. Drug Des Devel Ther. 2015;9:5269-5275.

12. Gande S, Kopparam M, Vemula S. Preparation, Characterization and in vitro and in vivo evaluation of Lovastatin solid lipid nanoparticles. AAPS PharmSciTech. 2007;8:E1-E9.

13. Mohammad HS, Sharmin S, Jahan I, Reza HM, Kazi M. The impact of process parameters on carrier free paracetamol nanosuspension prepared using different stabilizers by antisolvent precipitation method. J Drug Deliv Sci Technol. 2018;43:123-128.

14. Hamid RP. Preparation and characterization of azithromycin nanodrug using solvent/antisolvent method. Int Nano Lett. 2014;4:2-9.

15. Mansour M, Hamid RP, Vida V. Preparation and characterization of ibuprofen nanoparticles by using solvent/antisolvent precipitation. Open Conf Proc J. 2011;2:88-94.

16. Enubi C, Wonkyung C, Junsung P, Min SK. Enhanced dissolution of megestrol acetate microcrystals prepared by antisolvent precipitation process using hydrophilic additives. Int J Pharm. 2010;396:91-98.

17. Mohammad HS, S. Sharmin, I.Jahan, H.M.Reza, Kazi M. The impact of process parameters on carrier free Paracetamol Nanosuspension prepared using different stabilizers by antisolvent precipitation method. J Drug Deliv Sci Technol. 2018;43:123-128.

18. Bhupesh KA, Sunil KJ, Sharan KP, Surbhi B, Sarasija S. Formulation, optimization and in vitro-in vivo evaluation of febuxostat nanosuspension. Int J Pharm. 2015;478:540-552.

19. Rupall LS, Shashikant ND, Nilesh K, Santosh LS. Formulation and evaluation of nanosuspension delivery system for simvastatin. Int $\mathrm{J}$ Pharm Sci Nanotechnol. 2014;7:2459-2476.

20. Zhang T, Chen J, Zhang Y, Shen Q, Pan W. Characterization and evaluation of nanostructured lipid carrier as a vehicle for oral delivery of etoposide. Eur J Pharm Sci. 2011;43:174-179.

21. Patricia CD, Alejandro CO, Maria R. Rapid determination of paracetamol in blood serum samples by first-derivative UV absorption spectroscopy. Anal Lett. 1995;28:2219-2226.

22. Arpana PG, Varsha P. Montelukast-Loaded nanostructured lipid carriers: Part I Oral bioavaiability improvement. Eur J Pharm Biopharm. 2014;88:160-168.

23. Prabhat RM, Rainer HM. Production and characterization of hesperetin nanosuspensions for dermal delivery. Int J Pharm. 2009;371:182-189.

24. Wai KN, Sanggu K, Reginald BHT. Preparation and characterization of spironolactone nanoparticles by antisolvent precipitation. Int J Pharm. 2009;375:84-88. 
25. Roshan KP, Kalaiselvan S, Balamurugan K. In vivo pharmacokinetic studies to investigate the enhancement of bioavailability of lovastatin. J Pharm Int Bio Sci. 2018;3:19-25.

26. Keerthi P, Bhikshapath DVRN. Development and in vivo evaluation lovastatin by self-nanoemulsifying drug delivery System. Int J Pharm Sci Drug Res. 2018;10:165-172.
27. Gaber DA. Nanoparticles of lovastatin: design, optimization and in vivo evaluation. Int J Nanomedicine. 2020;15:4225-4236. 